Economics and Elections in Western Europe: 1960-1997*

\author{
Henry W. Chappell, Jr. \\ Department of Economics \\ University of South Carolina \\ Columbia, SC 29208 \\ chappell@darla.badm.sc.edu \\ and \\ Linda Gonçalves Veiga \\ Department of Economics \\ University of South Carolina \\ Columbia, SC 29208 \\ and \\ Escola de Economia e Gestão \\ Universidade do Minho \\ 4700 Braga, Portugal \\ linda@eeg.uminho.pt
}

* This paper was originally prepared for presentation at the Conference on Economics and Elections, Sandbjerg, Denmark, August 23-26, 1998. We acknowledge helpful comments from McKinley Blackburn, participants at the Conference on Economics and Elections, and participants in the University of South Carolina seminar series. Financial support for Linda Veiga was provided by the PRAXIS-XXI program, Fundação para a Ciência e a Tecnologia.

November 10, 1998 


\title{
Economics and Elections in Western Europe: 1960-1997
}

\begin{abstract}
This paper analyzes macroeconomic conditions and parliamentary election outcomes in 13 European countries over the 1960-1997 period. The analysis focuses on two themes. The first is that different macroeconomic theories imply that different economic indicators should be important for voters. The second is that political responsibility should condition voters' responses to economic performance. We estimate a model in which indicators of economic performance and political responsibility interactively determine election outcomes. Performance measures suggested by alternative theories are included in empirical specifications. Results suggest that changes in inflation, especially when measured relative to the European average, have an impact on incumbents' vote shares. The analysis fails to isolate political responsibility variables that condition the impact of economic performance on the vote, however.
\end{abstract}

Keywords: Elections, Voting, Macroeconomics, Europe 
This paper provides an empirical analysis of election outcomes, emphasizing voter responses to the macroeconomic performances achieved by incumbent governments. The general topic we pursue has been reconsidered frequently since Kramer (1971) studied Congressional and Presidential elections in the United States. Building on the work of Paldam (1991) and Powell and Whitten (1993), we seek to uncover and document general patterns of behavior which prevail consistently over time and across countries. To do so, we study 136 parliamentary elections in 13 European countries over the 1960-1997 period.

We focus on two themes in our work. The first theme involves the role of macroeconomic theories in developing measures of economic performance. Any study relating economic conditions to voting outcomes must confront the issue of how economic performance is to be measured. Frequently, the presumption has been that economic growth, unemployment, and inflation are appropriate performance measures. Accepting this presumption, the task of specification is reduced to questions of functional form; i.e., changes versus levels, lag lengths, nonlinearities, etc. While these matters are important, we believe that the more fundamental task of formulating standards of performance should not be neglected. Good performance should be judged in relation to what is feasible, as well as what is desirable. Macroeconomic theories have implications for feasibility constraints; as a consequence, different theories suggest different performance standards.

The second theme concerns the importance of political feasibility constraints. Once voters have assessed economic performance, they must still decide which politicians should be rewarded or punished. In most European countries, primary political responsibility rests with parties forming the government, rather than with a single elected executive. Because power and responsibility may be divided among multiple parties in a governing coalition, and because the composition of coalitions may change between elections, assessing political responsibility for economic outcomes is made more difficult. Uncovering general patterns in electoral outcomes is likely to require refined modeling of the political process.

\section{MACROECONOMIC THEORIES AND STANDARDS OF ECONOMIC PERFORMANCE}

We presume that incumbent politicians are rewarded when their performance is good in relation to what is deemed feasible. In macroeconomics, a theory can be thought of as a description of the relevant feasibility constraints. Holding underlying preferences about outcomes fixed, performance assessments will differ under differing perceptions about the correctness of alternative theories. In this section we describe 
some basic macroeconomic paradigms, and discuss how performance might be judged under each. To provide a reference point, we first introduce a conventional model of "economic voting" as developed in the absence of an explicit macroeconomic theory.

Economic Voting Without Explicit Macroeconomic Constraints

If there truly were no economic constraints, then voters would be disappointed if GDP were not infinitely high and work effort not infinitesimally small. Voters must recognize that some limitations exist, even if they are not aware of the precise form those limitations might take. Under these circumstances, it may be reasonable to suppose that voters marginally reward increases in conditions they like (higher output) and punish those they dislike (higher unemployment and higher inflation). A simple, conventional vote function could then take the following form:

$$
\Delta V_{t}=\beta_{0}+\beta_{1} \dot{Y}_{t}+\beta_{2} \Delta U_{t}+\beta_{3} \Delta \dot{P}_{t}
$$

This equation says that the election-to-election change in vote share for parties comprising the incumbent government, $\Delta V_{t}$, depends upon prevailing output growth, $\dot{Y}_{t}$, the change in unemployment, $\Delta U_{t}$, and the change in inflation, $\Delta \dot{P}_{t} \cdot{ }^{1}$ Equation (1) represents a typical starting point for studies of economics and elections.

Classical Macroeconomic Theory

Classical theory was broadly accepted prior to the Great Depression. Key premises of the classical theory are that the economy is constantly self-equilibrating and that the resulting equilibrium is characterized by full-employment. Under the classical view, the appropriate role for government is to enforce property rights and to tax and spend to provide appropriate levels of public goods. There is no role for active government efforts to manage aggregate demand in order to stabilize output. Inflation would be politically relevant in a classical economy unless the government were committed to a gold standard or fixed exchange rates. 
Early Keynesian Economic Theory

In contrast to classical theory, early Keynesian models asserted that government policymakers could manage output by appropriately manipulating monetary and fiscal policy instruments. In the absence of active government use of these tools, aggregate demand was thought to be unstable and perhaps prone to be deficient in relation to aggregate supply. A government performing its Keynesian policy functions well was one that recognized slumps in the private sector components of aggregate demand and intervened with the appropriate stimulus to prevent those slumps from deepening to recessions. Although inflation was not a primary concern when Keynes developed his theory, Keynesian economists soon recognized that inflation was a possible consequence of excessive aggregate demand when capacity constraints were binding.

The Keynesian model gives voters ample motive to punish and reward politicians based on economic performance. If policies produce full employment and price stability, politicians should be rewarded. If the economy suffers from high unemployment or inflation, politicians should be punished. The conventional vote function, in which electoral rewards depend on recent unemployment, output, and inflation, seems to fit well with Keynesian theory.

Several caveats should be noted, however. Keynesians recognized that zero unemployment was not feasible and that the boundary between full-employment and inflation was a fuzzy one. Because inflation might emerge before full capacity was reached, the relation between inflation and unemployment (or output) would be smooth rather than kinked. Empirically this phenomenon was documented by the Phillips curve (Phillips, 1958), which showed that inflation rates (in prices or wages) were inversely related to the level of the unemployment rate.

Given the existence of a Phillips Curve, conventional vote functions are deficient in at least two ways. First, they usually assume that voters have zero targets for both unemployment and inflation, even though these targets are not mutually feasible according to the Phillips curve constraint. Second, if the Phillips curve truly represents a constraint, the policymaker cannot independently control both unemployment and inflation. Once an unemployment rate is chosen, inflation is determined by the constraint relating the two variables. Phillips curves may also shift over time, in response to both exogenous shocks and to actions taken by policymakers. Thus, voters must decide whether favorable and unfavorable Phillips curve shocks are the responsibility of the policymaker or are the result of exogenous events beyond his control. 
Sometimes it might be possible for voters to recognize external shocks that are not controlled by policymakers. For example, a burst of inflation might result from an easily observed rise in the price of imported oil. Although many other exogenous shocks will not be easily observed, we can suggest an empirical approach to control for many of them. We make the plausible assumption that similar external shocks occur across countries simultaneously. If performance indicators are measured relative to the cross-country averages, shared shocks will be purged from consideration. ${ }^{2}$

The Natural Rate Hypothesis

Some early Keynesians interpreted the Phillips curve as a menu of permanent tradeoffs. Phelps (1967) and Friedman (1968) challenged this view, arguing that Phillips curve tradeoffs were illusory short-run phenomena. They argued that an equilibrium or "natural" rate of unemployment would exist whenever inflation was fully anticipated, regardless of the level of that inflation rate. This conclusion is now widely accepted by economists, and its political implications are striking. As William Nordhaus (1975) has shown, if short- and long-run Phillips curve tradeoffs differ and if voters punish current inflation and unemployment, then politicians have incentives to create political business cycles. Economic stimulus will create unsustainable pre-election booms, which are then followed by post-election inflations and contractions. The simple reward and punishment strategy implicit in conventional vote functions permits, and even encourages, politicians to manipulate the economy.

How would rational voters behave if they understood the natural rate hypothesis? First, voters would recognize that attempts to use aggregate demand policies to achieve unemployment rates below the natural rate would have only temporary success, and with a cost of persistent inflation. If inflation is considered undesirable, then a strong case can be made against driving unemployment rates below the natural rate via demand stimulation. Second, voters would recognize that if persistent inflation plagues the economy, it could be eradicated through contractionary policies that might temporarily increase unemployment. A reasonable long-run goal for voters with Phelps-Friedman beliefs is zero inflation at the natural rate of unemployment. Short-run policies should promote movement toward the attainment of the long-run goal. Thus, in inflationary times, voters should be willing to accept contractionary policies aimed at reducing inflation. Chappell (1983) and Chappell and Keech (1985) have proposed a performance measure to reflect such views; we describe their measure later in the discussion of our empirical work. 


\section{New Classical Theory}

Again consider the political business cycle theory. If that theory is correct, macroeconomic stimulus will occur regularly before elections. But if individuals fully understand the behavior of policymakers who engage in this manipulation, they would expect pre-election stimulus. Further, if markets equilibrate rapidly, the economy would quickly move to a long-run equilibrium with output and unemployment at their natural rates. If the stimulus is anticipated it will have no real effects on employment or output.

In the scenario just described expectations are formed "rationally," in the sense that individuals come to understand how systematic policy actions are undertaken and they understand the macroeconomic consequences of those policy actions (Muth, 1961). The result of the argument, that anticipated policy moves are powerless to influence real outcomes, applies to all systematic policy choices, not just those which might be politically motivated. Thus, ordinary countercyclical policy variations prescribed by Keynesian theory would be ineffective. Because of this policy ineffectiveness result, models incorporating both market-clearing and rational expectations assumptions are appropriately termed "new-classical" (Lucas, 1972; Sargent and Wallace, 1975).

Implications of the new classical view for vote functions are dramatic. Unsystematic policy variability can still lead to fluctuations, but such fluctuations would be undesirable. Voters would not reward growth and punish stagnation; rather, they would punish policy-induced variability in growth. Inflation remains a monetary phenomenon that is controllable by policymakers, so new classical views provide a rationale for its punishment.

\section{New Keynesian Theory}

New Keynesian theories (Fischer, 1977; Mankiw, 1985), accept the rational expectations assumption, but deny that markets clear instantaneously. Instead, new Keynesian models assume that nominal and/or real rigidities cause markets to adjust slowly to long-run equilibria. Such theories provide some rationale for government intervention to promote stability, much as in earlier Keynesian models.

Economists with new classical and new Keynesian views might agree that an appropriate goal of policy is to reduce the variability of output, while disagreeing on how this should be accomplished. New 
classicals would advocate simple policy rules to avoid government-induced shocks, while new Keynesians would be more likely to advocate conventional countercyclical stabilization policies. However, when monopoly power is the source of price stickiness in a new Keynesian model, the long-run equilibrium output level for an economy is sub-optimal. If this is the case, output increases might be considered desirable by voters, even when output already exceeds its natural rate.

\section{Real Business Cycle Theory}

Real business cycle (RBC) theorists (Kydland and Prescott ,1982; King and Plosser, 1984) generally accept the rational expectations and market clearing assumptions of the new classicals. However, their view of the causes of business cycles differs. New classical models attribute business cycle fluctuations primarily to unsystematic monetary policy shocks. Real business cycle theories instead attribute them to exogenous "productivity" shocks. As forward-looking individuals rationally react to these exogenous shocks, fluctuations in economic outcomes result. In the RBC view such fluctuations represent optimal responses to changes in technology. Thus, even if policymakers could influence real variables via fiscal and monetary policies, it would not be desirable to do so.

If productivity shocks are not controllable by politicians, voters should consider output levels to be politically irrelevant. Voters should not even punish variability of output, since fluctuations are optimal responses to shocks. However, inflation is again a controllable monetary phenomenon, and excessive inflation would be punished.

Our conclusions about the political implications of real business cycle models would differ if voters considered supply-side shocks to be controllable by government - and some supply shocks are controllable. Tax rates and special tax incentives, patent laws, development of infrastructure, and patterns of industrial subsidies could affect incentives for research, development, and innovation. ${ }^{3}$ More generally, regulatory institutions that affect market performance or the enforcement of property rights will also affect productivity. If productivity shocks are influenced by policymakers and are serially correlated within political administrations, then appropriate vote functions might once again look much like equation (1) (Rogoff and Sibert, 1988). Thus, a vote function like (1) might be indicative of voter naiveté under one view of economic constraints (as in the Nordhaus political business cycle model), but might be consistent with voter rationality under another. 
The RBC view does suggest several possible modifications of the conventional vote function, however. First, unemployment should probably be excluded from the model - it has no particular welfare relevance. Second, one might follow Peltzman (1990) in replacing output with consumption. Under the RBC view, agents have long planning horizons. Only productivity shocks that are expected to be permanent will have large impacts on consumption, so changes in consumption should reflect those productivity shifts that are expected to be largest and most enduring.

Summary

Different economic theories suggest differences in appropriate vote function specifications. Our discussion of prominent theories suggests that vote functions should consider the following added or modified performance indicators:

1. Performance variables can be expressed in relative terms, where neighboring economies provide the benchmark.

2. Under the natural rate hypothesis, the Chappell (1983) and Chappell-Keech (1985) performance measure can be used to measure the appropriate stance of countercyclical stabilization policy.

3. Unemployment and output can be expressed in the form of absolute deviations from non-zero targets. Natural rates of output and unemployment may provide appropriate targets.

4. Consumption growth can be used as a replacement for GDP growth

\section{POLITICAL RESPONSIBILITY FOR ECONOMIC OUTCOMES}

We have noted that evaluations should reflect assessments of what is macroeconomically feasible, as well as what is desirable. Evaluations should also reflect assessments of political powers and responsibilities (Anderson, 1998; Powell and Whitten, 1993). A politician is most likely to be held responsible for economic performance if he has the political authority to control policy instruments that provide leverage over economic outcomes. Although many aspects of the political environment are likely to affect the accountability of incumbents, in our empirical work we will focus on several of particular importance. First, we will distinguish single-party and coalition governments, as well as majority and minority governments. Second, the extent of a party's control of the parliament should be an indicator of its power and responsibility; the more dominant the 
majority, the clearer is the responsibility of the incumbent government. Third, the longer a government has been in office, the more likely it is that its policies produced the currently prevailing outcomes. Thus "older" governments should be more responsible for given outcomes. Finally, we note that in more open economies, macroeconomic outcomes are more likely to reflect external shocks. Openness should be associated with lower incumbent responsibility.

Previous studies of economics and elections have usually attempted to explain the aggregate vote share for incumbent parties, adding up across all parties in the governing coalition. However, the distinct member parties of the coalition are likely to differ in the extent to which they are responsible for economic outcomes; e.g. the largest party in a coalition is likely to be held more accountable than smaller parties. This suggests that it would be desirable to examine the vote shares of all parties in coalitions, without requiring that all such parties be held equally responsible by the voters. One contribution of our empirical analysis is to disaggregate and analyze incumbent vote totals in this way.

\section{AN EMPIRICAL SPECIFICATION FOR THE VOTE FUNCTION}

Our discussion suggests that votes for an incumbent government should be a function of appropriately measured economic performance in some period of time prior to the election. The extent to which performance is punished or rewarded should depend upon the extent to which an incumbent is politically responsible. We incorporate these ideas into a simple vote function via the following specification:

$$
\Delta V_{i t}=\gamma \mathbf{z}_{i t}+R\left(\mathbf{w}_{i t}\right) E\left(\mathbf{x}_{i t}\right)+e_{i t}
$$

In equation (2), the dependent variable $\Delta V_{i t}$ represents the election-to-election change in the share of the vote going to the incumbent government in country $i$ at time $t$. On the right-hand side, the vector $\mathbf{z}_{i t}$ includes noneconomic variables that might influence the vote. The $E\left(\mathbf{x}_{i t}\right)$ function defines overall economic performance as a function of the individual performance indicators included in the vector $\mathbf{x}_{i t}$. Overall economic

performance is multiplied by $R\left(\mathbf{w}_{i t}\right)$, a function which indicates the extent to which incumbents are rewarded or punished for economic performance. The $R$ function depends upon indicators of political responsibility included in the vector $\mathbf{w}_{i t}$. In practice, we will specify linear forms for the $R$ and $E$ functions. 
THE DATA SET

Our complete sample consists of 136 election observations occurring in 13 Western European countries (Austria, Belgium, Denmark, Finland, France, Germany, Ireland, Italy, the Netherlands, Portugal, Spain, Sweden, and the United Kingdom) over the 1960-1997 period. From this sample we have purged observations in which an incumbent government held office for less than one year, leaving us with a total of 116 observations. Missing values for some variables result in smaller samples in most estimated specifications.

For each of these election observations, we have recorded vote shares obtained by each party included in the governing coalition prior to the election. We have also recorded vote shares for the same parties in the previous election, so that we can construct a dependent variable as the change in vote share from election to election. Our election data permits us to classify governments as single-party or coalition governments and as majority or minority governments. We have also gathered data on unemployment, inflation (based on the consumer price index), real GDP, real consumption, and imports and exports. ${ }^{4}$

\section{EMPIRICAL RESULTS}

In our first set of results the dependent variable, $\Delta V_{i t}$, is the election-to-election change in vote share for the incumbent government. Initially, the incumbent vote share is defined as the sum of the shares of all parties participating in the government. We begin with a conventional vote function in which there are no interactive effects related to measures of responsibility (i.e., the $R$ function is a constant). We include the change in unemployment, $\Delta U_{i t}$, the change in the rate of inflation, $\Delta \dot{P}_{i t}$, and the growth rate of real GDP, $\dot{Y}_{i t}$, as performance indicators. Each of these variables is measured as a 4-quarter average, including the quarter in which the election is held.

Previous studies have found that incumbents' votes shares decline from election to election. Sometimes this effect is referred to as the "cost of ruling," implying that incumbent governments lose support as they alienate some supporters with decisions they make while in office. ${ }^{5}$ The longer they stay in office and the higher their vote shares in the preceding election the more likely it is that such losses will 
occur. To capture these effects we include VPREV $V_{i t}$ (the incumbent parties' vote share in the previous election) and $T I M E G_{i t}$ (the number of quarters the government has held office) ${ }^{6}$ in vector $\mathbf{z}_{i t}$ in our equation. Because we use panel data we have controlled for country-specific fixed effects in all regressions.

The first column of Table 1 provides results of the estimation of the "conventional" vote function. Although coefficients of the economic variables have the conventionally anticipated signs, only the change in the inflation rate differs significantly from zero at the 0.05 level. Coefficients of $T I M E G_{i t}$ and $V_{i t}$ are also significant, capturing cost-of-ruling effects. Results in the second column show that when unemployment is dropped from the model, income growth becomes marginally significant.

[Table 1 about here]

We next consider alternative performance measures. First we replace levels of unemployment and output with the same variables expressed as absolute values of deviations from trend values. ${ }^{7}$ These variables measure business cycle variability. The results in Table 1 are less favorable for this specification no economic variables are significant, and both the unemployment and output coefficients have unexpected signs. We next measured output growth, changes in unemployment, and changes in inflation as deviations from the European averages for the same variable. ${ }^{8}$ In this estimation, the coefficient of the relative change in inflation variable is negative and significant, this time at the 0.01 level. The growth and unemployment change variables are correctly signed, but insignificantly different from zero. The real business cycle model suggests that consumption growth should be more relevant politically than output growth; it also suggests that unemployment should be irrelevant. The fifth column of Table 1 provides results where consumption growth replaces output growth and unemployment has been dropped from the model. Although correctly signed, consumption growth is insignificantly different from zero.

We have noted that Chappell (1983) and Chappell and Keech (1985) have proposed a performance measure appropriate for economies that have Phillips curves of the Phelps-Friedman variety. Chappell and Keech define $Z_{i t}$ as the ratio of output to its natural rate less one; i.e., $Z_{i t}=Y_{i t} / Y N_{i t}-1$. They then argue that the "optimal" level for this variable, denoted $Z_{i t}^{*}$, depends on the rate of inflation. Specifically they assume that $Z_{i t}^{*}=d \pi_{i t-1}$, where $d \leq 0$. The rationale for this specification is that when inflation is positive, 
contractionary policy is appropriate, and $Z_{i t}$ should be negative (i.e., output should be less than its natural rate). Chappell and Keech then measure performance, $S_{i t}$, as the squared deviation of actual from optimal policy; i.e., $S_{i t}=\left(Z_{i t}-Z_{i t}^{*}\right)^{2}=\left(Y_{i t} / Y N_{i t}-1-d \pi_{i t-1}\right)^{2}$. Higher values of $S_{i t}$ indicate lower levels of performance. ${ }^{9}$ In the last column of Table 1, we report results for this specification. Neither the coefficient of $S_{i t}$ nor that of $d$ differs significantly from zero.

To this point, our estimations produce weak evidence for conventional vote function specifications, and, except for the use of relative measures, no evidence for any of the modified performance measures. However, if the degree of political responsibility for economic performance systematically varies over time, countries, governments, or parties within the government, we require the richer empirical specification described by equation (2) and more disaggregated voting data. For the remainder of our analysis, we employ a sample in which observations are defined for each incumbent party in each election. E.g., if four parties are governing in a coalition prior to an election, then that election generates changes in vote shares for each of those four parties and produces four observations in our data set. ${ }^{10}$ With such a sample, it is natural to investigate how responsibility varies across the parties in a coalition.

We define economic performance, $E$, to be a linear combination of economic performance measures, e.g.:

$$
E\left(\mathbf{x}_{i t}\right)=\beta_{1} \Delta U_{i t}+\beta_{2} \Delta \dot{P}_{i t}+\beta_{3} \dot{Y}_{i t}
$$

Responsibility, $R$, is defined as:

$$
R\left(\mathbf{w}_{i t}\right)=\alpha_{0}+\alpha_{1} \text { OPEN }_{i t}+\alpha_{2} C O A L_{i t}+\alpha_{3} M_{i t}+\alpha_{4} T_{I M E P_{i t}}+\alpha_{5} V P R E V_{i t}+\alpha_{6} M_{A I N},
$$

where $O P E N_{i t}$ measures the extent of openness of the economy (imports plus exports divided by GDP), $C O A L_{i t}$ is a dummy variable indicating a coalition government in office prior to the election, $M I N_{i t}$ is a dummy variable indicating that the incumbent government controls a minority of the parliament, $T I M E P_{i t}$ is the number of quarters the incumbent party has been in office, $V P R E V_{i t}$ is the vote share of that party in the preceding election, and $M A I N_{i t}$ is a dummy variable indicating the largest party in a coalition. 
In Table 2 we report selected estimates of this model using a subset of the economic performance variables considered earlier. ${ }^{11}$ Using alternative indicators did not produce results notably better than those reported in the table. ${ }^{12}$ First excluding the responsibility variables, estimates of conventional vote functions indicate that the change in inflation and the change in inflation relative to the European average are significant explanatory variables; economic growth falls just short of significance when unemployment is dropped from the model. When variations in responsibility are included, only the specification in which performance measures are defined relative to European averages produce significant impacts of economic conditions. The change in inflation and the change in unemployment are both correctly signed and significantly different from zero. Two variables in the responsibility vector, $T I M E P_{i t}$ and $O P E N_{i t}$, also differ significantly from zero, but only $O P E N_{i t}$ is correctly signed. Moreover, when the improperly signed $T_{I M E P}$ it variable is dropped from the specification, no economic variable coefficients differ significantly from zero. Given the failure of the responsibility measures to influence vote shares in the hypothesized manner, we must conclude that there is little support for the conjecture that variations in political responsibility can account for the instability of vote function parameter estimates across countries. ${ }^{13}$ These negative results are robust; our findings are similar when the set of included responsibility indicators is varied or when samples of governments or largest parties are used in lieu of the sample of all governing parties.

[Table 2 about here]

Conclusions

We have constructed a data set describing economic conditions and election outcomes in 13 Western European countries over the 1960 to 1997 period. With this data set, we investigated the performance of a variety of vote function specifications. Our purpose was to assess the relative performance of vote functions motivated by alternative economic paradigms and to account for variations in the extent to which incumbent parties are held responsible for economic outcomes. We have found some evidence to support the general hypothesis that economic outcomes affect election outcomes. However, we have been unable to isolate any measures of political responsibility measures that convincingly affect voting, and our inferences about voters' macroeconomic beliefs remain speculative. 
Our strongest finding is that voters punish increases in inflation, especially those that exceed the European average. In almost all macroeconomic theories (including all of those surveyed here) inflation is considered to be both undesirable and controllable by policymakers, so it is reassuring to find that voters punish it. But because inflation aversion is consistent with all theories, this finding alone does not help us to distinguish between the alternative macroeconomic paradigms that voters might employ.

We find weaker evidence for the hypothesis that voters reward growth of real output. Economic growth is marginally significant in some specifications and insignificant in others. The weakness of the output effects might indicate that voters think growth is less important than inflation or, alternatively, that they think it is less controllable than inflation. Given the intrinsic importance of output growth to standards of living, we find that the latter interpretation is more plausible a priori. This might lead one to characterize voters as "non-Keynesian," but we are reluctant to go too far in this direction. Performance measures specific to non-Keynesian models (e.g. output variability or real consumption growth) did not perform well in our estimations. Until a better explanation is developed, we should probably view voters as most of the literature does: voters reward outcomes they like and punish those that they dislike subject to imperfect, but not grossly inadequate, perceptions of constraints. 


\section{References}

Anderson, C.A. (1998) Economic voting and political context. Electoral Studies, this issue.

Chappell, H.W., Jr. (1983) Economic performance and presidential popularity: Are voters really so naïve? Review of Economics and Statistics 65, 385-92.

Chappell, H.W., Jr. and Keech, W.R. (1985) A new view of political accountability for economic performance. American Political Science Review 79, 10-27.

Fischer, S. (1977) Long-term contracts, rational expectations, and the optimal money supply rule. Journal of Political Economy 85, 191-205.

Friedman, M. (1968) The role of monetary policy. American Economic Review 58, 1-17.

Hodrick, R. J. and Prescott, E. C. (1997) Postwar U.S. business cycles: an empirical investigation. Journal of Money, Credit and Banking 29, 1-16.

King, R. and Plosser, C. (1984) Money, credit, and prices in a real business cycle. American Economic Review 64, 363-380.

Kydland, F. E. and Prescott, E. C. (1982) Time to build and aggregate fluctuations. Econometrica 50, 13451370.

Kramer, G. (1971) Short-term fluctuations in U.S. voting behavior, 1896-1964. American Political Science Review 65, 131-143.

Lucas, R. E., Jr. (1972) Expectations and the neutrality of money. Journal of Economic Theory 4, 103-24.

Mankiw, N. G. (1985) Small menu costs and large business cycles: a macroeconomic model of monopoly. Quarterly Journal of Economics 100, 529-39.

Muth, J. (1961) Rational expectations and the theory of price movements. Econometrica 39, 315-34.

Nordhaus, W. D. (1975) The political business cycle. Review of Economic Studies 42, 169-190.

Paldam, M. (1991) How robust is the vote function?: A study of seventeen nations over four decades. In Economics and Politics: The Calculus of Support, ed. H. Norpoth, M.S. Lewis-Beck, and J. Lafay. Ann Arbor: University of Michigan Press, 9-31.

Peltzman, S. (1990) How efficient is the voting market? Journal of Law and Economics 33, 27-63.

Phelps, E. (1967) Phillips curves, expectations of inflation and optimal unemployment over time.

Economica 34, 254-281. 
Phillips, A. W. (1958) The relationship between unemployment and the rate of change of money wages in the United Kingdom. Economica 25, 283-289.

Powell, G. B., Jr., and Whitten, G. (1993) A cross-national analysis of economic voting: taking account of the political context. American Journal of Political Science. 37, 391-414.

Rogoff, K. and Sibert, A. (1988) Elections and macroeconomic policy cycles. Review of Economic Studies 55, 1-16.

Sargent, T., and Wallace, N. (1975) Rational expectations, the optimal monetary instrument, and the optimal money supply rule. Journal of Political Economy 83, 241-254. 


\section{Notes}

${ }^{1}$ The vote function is sometimes specified in levels rather than changes of the included variables. We follow the example of Paldam (1991), who argues that, because levels of some economic indicators have differed widely across countries, it is more plausible that voters will evaluate changes similarly.

${ }^{2}$ Powell and Whitten (1993) report empirical evidence to support the use of relative performance measures in their study of elections across countries.

${ }^{3}$ Government spending will also have direct supply-side consequences in a real business cycle model. For example, wasteful government spending would simultaneously increase measured real GDP (by inducing more work effort) and reduce welfare.

${ }^{4}$ Appendices describing data sources in detail are available from the authors upon request.

${ }^{5}$ Another explanation for this effect is that it is a statistical artifact. Because the parties forming an incumbent government usually did well in the preceding election, it is likely that they received a positive error term for that observation. In the current election, the government's error term is likely to be average rather than favorable, implying that its vote share should decrease.

${ }^{6}$ When the composition of a government changes between elections, we measure time in office as the number of quarters that the coalition currently ruling has been in office.

${ }^{7}$ Trends and deviations were obtained via the Hodrick-Prescott filter (Hodrick and Prescott, 1997). We follow their example (and common practice) in setting the parameter $\lambda$ equal to 1600 in separating trends and deviations for quarterly series. The setting of $\lambda$ determines how closely trend values track actual values of a series.

${ }^{8}$ The average is measured over the same 13 countries comprising our sample.

${ }^{9}$ In calculating this variable, we employ trends calculated via the Hoderick-Prescott filter to measure natural rates of output.

${ }^{10}$ With observations defined for each party in this way, our sample size increases from 116 to 272 observations. In this sample, $i$ now indexes party-country pairs in the sample.

${ }^{11}$ For this specification, in addition to including country fixed-effects we also tested for election fixedeffects. Election-specific dummy variables were not jointly significant and were subsequently excluded from the model. 
${ }^{12}$ There is one minor exception to this statement. Consumption growth performed slightly better than GDP growth in an equation analogous to that provided in the second column.

${ }^{13}$ Using a sample of countries where clarity of governmental responsibility is high, Powell and Whitten (1993) find that right-wing governments are punished for high comparative inflation and that left-wing governments are punished for high comparative unemployment. When we introduce similar partisaninteracted economic variables into our own specifications, we do not find consistent support for such effects. 
Table 1. Vote Functions With Alternative Measures of Economic Performance

\begin{tabular}{|c|c|c|c|c|c|c|}
\hline Vote share in preceding election & $\begin{array}{l}-.31 * * * \\
(-3.68)\end{array}$ & $\begin{array}{l}-.27 * * * \\
(-3.82)\end{array}$ & $\begin{array}{l}-.29 * * * \\
(-3.38)\end{array}$ & $\begin{array}{l}-.31 * * * \\
(-3.85)\end{array}$ & $\begin{array}{l}-.17^{* *} \\
(-2.02)\end{array}$ & $\begin{array}{l}-.27 * * * \\
(-3.72)\end{array}$ \\
\hline Quarters in office & $\begin{array}{l}-.48 * * * \\
(-2.79)\end{array}$ & $\begin{array}{l}-.40 * * * \\
(-2.68)\end{array}$ & $\begin{array}{l}-.51 * * * \\
(-2.91)\end{array}$ & $\begin{array}{c}-.49 * * * \\
(-2.95)\end{array}$ & $\begin{array}{l}-.69 * * * \\
(-3.13)\end{array}$ & $\begin{array}{l}-.40 * * * \\
(-2.60)\end{array}$ \\
\hline $\begin{array}{l}\text { Economic performance variables } \\
\text { Changes in Inflation }\end{array}$ & $\begin{array}{l}-6.79 * * \\
(-2.05)\end{array}$ & $\begin{array}{l}-5.15^{* *} \\
(-2.21)\end{array}$ & $\begin{array}{l}-5.55 \\
(-1.65)\end{array}$ & & $\begin{array}{l}-3.38 \\
(-.86)\end{array}$ & \\
\hline Changes in Unemployment & $\begin{array}{l}-2.42 \\
(-.88)\end{array}$ & & & & & \\
\hline Real GDP growth rate & $\begin{array}{l}1.00 \\
(.95)\end{array}$ & $\begin{array}{l}1.66^{*} \\
(1.91)\end{array}$ & & & & \\
\hline $\begin{array}{l}\text { Absolute Deviation of Unemployment } \\
\text { from Trend }\end{array}$ & & & $\begin{array}{l}1.76 \\
(.86)\end{array}$ & & & \\
\hline $\begin{array}{l}\text { Absolute Deviation of Real GDP from } \\
\text { Trend }\end{array}$ & & & $\begin{array}{l}-21.09 \\
(-.26)\end{array}$ & & & \\
\hline Changes in Relative Inflation & & & & $\begin{array}{c}-10.70^{* * *} \\
(-2.97)\end{array}$ & & \\
\hline Changes in Relative Unemployment & & & & $\begin{array}{l}-.73 \\
(-.22)\end{array}$ & & \\
\hline Relative real GDP growth rate & & & & $\begin{array}{c}1.26 \\
(1.12)\end{array}$ & & \\
\hline Real Private Consumption Growth Rate & & & & & $\begin{array}{c}1.66 \\
(1.21)\end{array}$ & \\
\hline Chappell-Keech Economic Performance & & & & & & $\begin{array}{c}-552.66 \\
(-.65)\end{array}$ \\
\hline Chappell-Keech parameter $d$ & & & & & & $\begin{array}{l}.01 \\
(.80)\end{array}$ \\
\hline Adjusted R-squared & 0.304 & 0.282 & 0.287 & 0.340 & 0.179 & 0.230 \\
\hline
\end{tabular}

NOTE: The coefficients on the dummies included to control for fixed effects are not reported. t-statistics are in parentheses.

*** significant at the $1 \%$ level; ** significant at the $5 \%$ level; * significant at the $10 \%$ level. 
Table 2. Vote Functions Explaining Individual Governing Party Vote Shares

\begin{tabular}{|c|c|c|c|c|c|c|}
\hline Vote Share In Preceding Election & $\begin{array}{l}-.07 * * * \\
(-2.94)\end{array}$ & $\begin{array}{r}-.07 * * * \\
(-3.22)\end{array}$ & $\begin{array}{l}-.08 * * * \\
(-3.07)\end{array}$ & $\begin{array}{l}-.08 * * * \\
(-2.76)\end{array}$ & $\begin{array}{l}-.08 * * * \\
(-2.93)\end{array}$ & $\begin{array}{l}-.07 * * \\
(-2.38)\end{array}$ \\
\hline Quarters in Office & $\begin{array}{l}-.19 * * \\
(-2.30)\end{array}$ & $\begin{array}{l}-.19 * * \\
(-2.58)\end{array}$ & $\begin{array}{l}-.20 * * \\
(-2.37)\end{array}$ & $\begin{array}{l}-.16 \\
(-1.50)\end{array}$ & $\begin{array}{l}-.23 * * \\
(-2.51)\end{array}$ & $\begin{array}{l}-.24 * * \\
(-2.48)\end{array}$ \\
\hline $\begin{array}{l}\text { Responsibility variables } \\
\text { Main Party }\end{array}$ & & & & $\begin{array}{c}.94 \\
(.30)\end{array}$ & $\begin{array}{l}.11 \\
(.56)\end{array}$ & $\begin{array}{l}-.69 \\
(-.33)\end{array}$ \\
\hline Vote Share in Preceding Election & & & & $\begin{array}{l}-.06 \\
(-.36)\end{array}$ & $\begin{array}{c}.4 \mathrm{E}-02 \\
(.56)\end{array}$ & $\begin{array}{l}-.02 \\
(-.52)\end{array}$ \\
\hline Quarters in Office & & & & $\begin{array}{c}-.5 \mathrm{E}-02 \\
(-.04)\end{array}$ & $\begin{array}{l}-.05^{* * *} \\
(-4.51)\end{array}$ & \\
\hline Coalition Government & & & & $\begin{array}{l}-.99 \\
(-.34)\end{array}$ & $\begin{array}{l}.38 \\
(1.44)\end{array}$ & $\begin{array}{l}-2.22 \\
(-.65)\end{array}$ \\
\hline Minority Government & & & & $\begin{array}{l}5.30 \\
(.32)\end{array}$ & $\begin{array}{c}-.23 \\
(-1.36)\end{array}$ & $\begin{array}{l}1.09 \\
(.63)\end{array}$ \\
\hline Degree of Openness & & & & $\begin{array}{l}.59 \\
(.19)\end{array}$ & $\begin{array}{l}-.50 * * \\
(-2.19)\end{array}$ & $\begin{array}{l}-.44 \\
(-.23)\end{array}$ \\
\hline $\begin{array}{l}\text { Economic performance variables } \\
\text { Changes in Inflation }\end{array}$ & $\begin{array}{c}-3.82 * * \\
(-2.05)\end{array}$ & $\begin{array}{r}-2.86^{* *} \\
(-2.21)\end{array}$ & & $\begin{array}{c}.82 \\
(.31)\end{array}$ & & \\
\hline Changes in Unemployment & $\begin{array}{l}-1.36 \\
(-1.05)\end{array}$ & & & $\begin{array}{c}-.03 \\
(-.34)\end{array}$ & & \\
\hline Real GDP Growth Rate & $\begin{array}{l}.36 \\
(.82)\end{array}$ & $\begin{array}{l}.56 \\
(1.54)\end{array}$ & & $\begin{array}{l}.73 \\
(.34)\end{array}$ & & \\
\hline \multicolumn{7}{|l|}{ Real Private Consumption Growth Rate } \\
\hline Changes in Relative Inflation & & & $\begin{array}{c}-4.80 * * \\
(-2.40)\end{array}$ & & $\begin{array}{c}-29.47 * * * \\
(-2.64)\end{array}$ & $\begin{array}{l}6.10 \\
(.75)\end{array}$ \\
\hline Changes in Relative Unemployment & & & $\begin{array}{l}-.64 \\
(-.44)\end{array}$ & & $\begin{array}{c}-19.30 * * \\
(-2.03)\end{array}$ & $\begin{array}{l}.84 \\
(.64)\end{array}$ \\
\hline Relative Real GDP Growth Rate & & & $\begin{array}{l}.76 \\
(1.48)\end{array}$ & & $\begin{array}{l}-2.22 \\
(-.97)\end{array}$ & $\begin{array}{l}-.20 \\
(-.52)\end{array}$ \\
\hline Adjusted R-squared & 0.111 & 0.119 & 0.120 & 0.125 & 0.143 & 0.099 \\
\hline
\end{tabular}

NOTE: The coefficients on the dummies included to control for fixed effects are not reported. $\mathrm{t}$-statistics are in parentheses.

*** significant at the $1 \%$ level; ** significant at the 5\% level; * significant at the $10 \%$ level. 